\title{
DIDAKTICKÉ ASPEKTY NUMISMATICKÝCH SBÍREK V MUZEÍCH
}

\section{MONIKA MAŽÁROVÁ}

\section{ABSTRAKT/ABSTRACT:}

Numismatické sbírkové předměty zůstávají často pro svoji náročnější interpretaci, zapřričiněnou velikostí i specifickým charakterem, stranou soustavnější pozornosti návštěvníků. Odcházejí ochuzeni o bohatost sdělení a tematickou šíri numismatických pramenů. Své uplatnění v plném rozsahu zde tak nachází muzejní edukace pomáhající skrze didaktické prostředky, výukové metody a cílené edukační programy zprostředkovat návštěvníkům svědectví ukrytá (nejen) v mincích. Přináší rovněž do muzejního prostředí téma finanční gramotnosti, které společně s budováním respektu ke kulturnímu dědictví a jeho ochraně podtrhuje společenský prrínos muzea.

\section{Didactic aspects of numismatic collections in museums}

Numismatic collectibles often stay apart from a systematic attention of visitors due to their complicated interpretation based on the size and specific qualities of individual items. Visitors are thus deprived of the information wealth and thematic width of numismatic sources. This situation creates space for museum education, which uses didactic tools, teaching methods and targeted educational programmes to communicate to visitors the information hidden (not only) in coins. It also enriches the spectrum of museum themes with financial literacy. This topic, along with the development of respect towards the cultural heritage and its protection, accentuates the social benefit of museums.

\section{KLÍČOVÁ SLOVA/KEYWORDS:}

muzejní edukace - muzejní didaktika - oborová didaktika numismatika - finanční gramotnost museum education - museum didactics - disciplinary didactics numismatics - financial literacy

Mince patří k frekventovaným sbírkovým předmětům českých i světových muzeí, tvoří samostatné numismatické expozice či součást historických výstav. Mince v nich dokládají stav tehdejší společnosti - její politiku, prosperitu a vyspělost. Ukazují obchodnické cesty a významná hospodářská centra. Jsou jedním z mála svědectví o existenci dávno zaniklých civilizací a jejich kultuře. I přes nepopíratelný význam pro historii, archeologii, ekonomii a řadu dalších vědních oborů však zůstávají numismatické exponáty obvykle návštěvníky přehlédnuty, nedoceněny nebo nedostatečně interpretovány.

Běžný návštěvník často nedokáže ani při ideální instalaci plně vytěžit tento typ pramene poznání, přestože se jedná o předměty tvořící již přes 2000 let součást každodenního života lidstva. Snad právě onen všední kontakt s penězi v běžném životě snižuje ve srovnání s „exkluzivnějšími“" exponáty
https://doi.org/10.5817/MuB2021-1-3

emociální působivost mincí (byt’ v jejich původní historické podobě), a tím také zájem návštěvníků. Dalším z faktorů je jednoduše jejich velikost a problematická instalace. S ohledem na ochranu a bezpečnost sbírkového předmětu nelze obvykle pustit návštěvníka $\mathrm{k}$ mincím do bezprostředního kontaktu pro blízké pozorování a vnímání, které je při studování mincí nezbytné. Obdobnou bariéru jako velký odstup a sklo vitríny mezi návštěvníkem a svědectvím ukrytým v mincích vytváří také chybějící orientace v numismatickém oboru postupech, metodách i pojmech poskytující návod, jak tyto exponáty vnímat.

Všechny výše naznačené bariéry pomáhá návštěvníkovi odstranit muzejní edukace. Vhodným didaktickým přístupem, tj. výběrem metod, forem i didaktických prostředků, poutá pozornost k numismatickým exponátům, zvyšuje zájem o tento obor a usnadňuje zprostředkování muzeality v nich ukryté. Přesto dosud $\mathrm{v}$ teorii nebyl publikován text poskytující muzejním pedagogům metodickou podporu specifickou pro zprostředkování numismatických sbírek. Cíl tohoto článku tak spočívá v propojení dosud publikovaných kusých poznatků z oblasti interpretace numismatických sbírek, základů obecné muzejní didaktiky se zkušenostmi z autorčiny vlastní praxe i dohledanými příklady.

Text nejprve pro základní náhled do tématu stručně vysvětlí 
charakteristiku a metody numismatického oboru, aby následně navázal postupy muzejní edukace - od užšího výběru konkrétních exponátů pro muzejně edukační programy přes nabízené výukové metody i didaktické prostředky až k tematickým rovinám, na něž lze muzejní edukaci zaměřit.

\section{Úvodní numismatický exkurz}

Numismatika, řazena mezi pomocné vědy historické, ${ }^{1}$ se etablovala do samostatného historického vědního oboru zabývajícího se technikou peněžní směny již od předmincovního období. ${ }^{2}$ Pro svoji badatelskou práci využívá hned několik pramenů. Primárním, hmotným pramenem studia zůstávají ovšem platidla v nejrůznějších podobách doplněná o numismatické katalogy, díky nimž se do současnosti dochovaly některé historické ražby alespoň v dokumentační, kresebné reprodukci. Svoji výpovědní hodnotu mají rovněž hromadné nálezy mincí, tzv. depoty.

Obdobně důležité jsou rovněž tzv. nemincovní prameny doplňující „neúplnost historické výpovědi minci“ ${ }^{3}$ například listinné prameny - od dokumentů finančního charakteru až po kroniky. Komplexní poznání v rámci numismatiky umožňují také prameny pomocné, jakými mohou být např́íklad dochované nástroje na výrobu mincí, razidla, mincovní závaží nebo žetony a medaile. Různorodost pramenné

1 HLAVÁČEK, Ivan, Rostislav NOVÝ a Jaroslav KAŠPAR. Vademecum pomocných věd historických. Jinočany: H \& H, 2002, s. 397.

2 PETRÁŇ, Zdeněk a Pavel RADOMĚRSKÝ. Encyklopedie české numismatiky. Praha: Libri, 1996, s. 13.

3 KURZ, Karel. Metodika prezentace numismatického materiálu. In SEJBAL, Jiří (ed.). Vzdělávací a kulturně výchovná činnost $v$ numismatice: sborník materiálů z numismatického semináře v Brně 1976. Brno: Moravské muzeum v Brně, Numismatické oddělení, 1979, s. 20. základny poukazuje na provázanost numismatiky s jinými vědními obory a zároveň na širokou škálu sdělení, která numismatik při zpracování mince odkrývá.

Badatel musí v první fázi zvládnout platidla určit geograficky, historicky, faktograficky (tj. místo vzniku, datace, nominální hodnota, materiál, hmotnost a velikost atd.). Poté přistupuje $\mathrm{k}$ jejich ikonografickému a uměleckohistorickému rozboru s pomocí heraldiky, vymezuje je v ekonomickém a právním systému (nominální a reálná hodnota), čímž postupně vydává zprávu o stavu společnosti - politické a hospodářské prosperitě. Aby toto cenné svědectví nezůstávalo pro nepoučeného návštěvníka přes výše uvedené bariéry skryto, nabízí se využití teoretických i praktických nástrojů muzejní edukace.

\section{Muzejní edukace ve službách numismatiky}

Základní prostředek k usnadnění interpretace numismatických exponátů spočívá ve vhodném výběru konkrétních exponátů reprezentujících určené téma. Muzejní edukace díky poznatkům převzatým z obecné pedagogiky a psychologie dokáže pro konkrétní edukační program účinně vybrat mezi vystavenými mincemi vhodné zástupce k odkrývání stanovených tematických rovin. Volba exponátů stěžejních pro daný edukační program musí vycházet z poznání numismatického oboru a z definovaných výukových cílů programu. ${ }^{4}$ Důležitá je rovněž výpovědní hodnota exponátu pro sledované téma, jeho velikost a stav.

\footnotetext{
4 O formulování výukových cílů blíže např̀ ŠOBÁŇOVÁ, Petra a Michaela JOHNOVÁ ČAPKOVÁ. Plánování edukačních aktivit v muzeu: od strategického plánu k př́pravě edukačního programu. Olomouc: Univerzita Palackého v Olomouci, 2015, s. 76-79.
}

Kromě muzeologické a interpretační roviny se musí zohlednit také praktická rovina př́stupnosti exponátů. Ta je pro specifika pozorování a vnímání numismatických exponátů stěžejní. Právě u drobných mincí je nutné sledovat, zda se k nim návštěvník v průběhu edukačního programu pohodlně dostane na nejbližší možnou vzdálenost respektující ochranu sbírkového předmětu. Důležitý zůstává celkový způsob instalace včetně dobrých světelných podmínek. Tento cílený výběr představuje jeden ze stěžejních faktorů úspěšné muzejní edukace. Jeho význam spočívá mimo jiné i v usnadnění soustředěné pozornosti a orientaci ve velkém množství obdobných exponátů.

Eliminovat přesycení podněty či odvádění pozornosti pomáhají nejrůznější didaktické prostředky. Jednoduchou, ale účinnou pomůckou v tomto ohledu může být například obyčejný neprůhledný jednobarevný papír velikosti minimálně $A 4 s$ vystřiženým otvorem, který se na nezbytně nutnou dobu trvání dané aktivity v průběhu edukačního programu přiloží $\mathrm{k}$ vitríně. ${ }^{5}$ Pokud to způsob instalace umožňuje, nabízí se dále možnost využít zvětšovacích lup, př́ípadně vizualizéru s funkcí zvětšování, díky němuž přiblíží muzejní pedagog během edukačního programu drobný exponát větší skupině návštěvníků najednou bez nepřehledného seskupování před vitrínou. Funkčními didaktickými prostředky zůstávají rovněž reprodukce.

Obrazový materiál nejen usnadňuje studium a poznání drobných numismatických exponátů, ale také doplňuje muzejní edukaci o předměty, které není možné

5 Obdobná pomůcka, tzv. čtecí okénko, je úspěšně aplikována při nácviku čtení u dětí s dyslexií. 


\section{Ceny zboží ve 14 . století}

Ceny zboží v 15. století

\begin{tabular}{|l|l|}
\hline Kůň 240 grošů & Kůň 120 grošů \\
\hline Kráva 55 grošů & Kráva 32 grošů \\
\hline
\end{tabular}

Týdenní mzda tesaře ve 14 . století

Týdenní mzda tesaře v 15 . století

18 grošů

12 grošů

Tab. 1: Srovnávací tabulka cen a mezd ve 14. a 15. století. ${ }^{7}$

představit $\mathrm{v}$ jejich hmotné podobě. ${ }^{6}$ Z didaktických prostředkù listinného charakteru lze dále do edukačního programu začlenit snadno dostupné informace a tabulky ukazující převody historických měn, dobovou hodnotu dané měny včetně její proměny v průběhu historie (viz ukázka z publikace Encyklopedie české numismatiky - Tab. 1), s nimiž lze například v rámci edukačního programu pracovat formou nejrůznějších matematických úloh porovnávajících ceny zboží a výši mezd.

Hlavní úsilí muzejní edukace by však mělo náležet v umožnění co nejbližšího kontaktu návštěvníka s hmotným sbírkovým předmětem v souladu s přetrvávajícím trendem hands-on. Problematikou rovnováhy mezi zpřístupněním numismatických sbírkových předmětů a jejich ochranou se zabýval ve své studii již před deseti lety John Orna-Ornstein z British Museum: „Neexistuje žádný důvod, proč by nemělo být s mincemi z muzejních sbírek manipulováno $v$ kontrolovaném a bezpečném prostředí. My využíváme tímto způsobem téměr v̌̌echny části sbírky pro odborníky, širokou veřejnost a dokonce pro

\footnotetext{
6 K vhodným obrazovým reprodukcím patří například vyobrazení středověké mincovny na grafice Hanse Burgkmaira staršího

z 15./16. století nebo obdobný výjev na nástěnné malbě v Mincíršsé kapli chrámu sv. Barbory v Kutné Hoře z konce 15. století.

7 PETRÁŇ, Zdeněk a Pavel RADOMĚRSKÝ. Encyklopedie české numismatiky. Praha: Libri, 1996, s. 55.
}

školní skupiny. “8 Zároveň však přiznává, že ne každý předmět je vhodný $\mathrm{k}$ přímé manipulaci (vzácné exempláře, chatrné atp.), a zdůrazňuje nezbytnou bezpečnost místa ke kontrolované manipulaci (např. badatelna, muzejní učebna). $S$ běžně dostupnými mincemi a mincemi malé hodnoty však dle Orna-Ornsteinova přesvědčení lze zacházet také v méně bezpečném prostředí.

Přes 60 let starý, ale pro současnost neobvyklý, příklad bližšího zpřístupnění sbírkových předmětů mimo muzejní prostředí zmiňuje sborník numismatického semináře z roku 1976. ${ }^{9}$ Jako príkladnou spolupráci mezi školou a muzeem uvádí historicko-vlastivědný kroužek základní školy v Miroslavi na Znojemsku. Tamní žáci odkryli nález mincí z 15. století a odevzdali jej numismatickému oddělení Moravského zemského muzea v Brně. Jako poděkování jim muzeum zapůjčilo do školy pro

\footnotetext{
8 ORNA-ORNSTEIN, John. Coins are small and boring: the importance of an education programme for a numismatic collection. In Actas de la VIII reunión del Comité Internacional de Museos Monetarios y Bancarios (ICOMON) = Proceedings of the 8th Meeting of the International Committee of Money and Banking Museums (ICOMON), Barcelona, 2001 [online]. Barcelona: Museu Nacional d'Art de Catalunya, 2003, s. 98 [cit. 2021-01-22]. Dostupný z www: <http:// network.icom.museum/fileadmin/user_upload/ minisites/icomon/publications/e-proceedings pre_2006/Barcelona_2001/John_Orna-Ornstein/ Coins_are_small_and_boring_tthe_importance. of_an_education_programme_for_a_numismatic collection.pdf $>$.

9 SEJBAL, Jiří. Zhodnocení a perspektiva kulturně výchovné práce $\mathrm{v}$ numismatice $\mathrm{v}$ našich zemích. In SEJBAL, Jiří (ed.). Vzdělávací a kulturně výchovná činnost v numismatice: sborník materiálu z numismatického semináře v Brně 1976. Brno: Moravské muzeum v Brně, 1979, s. 14.
}

výstavní a edukační účely soubor mincí z vlastní sbírky.

V kontrastu s těmito tendencemi však např́iklad autoři publikace Muzejní pedagogika připomínají výchovný efekt tradičního muzejního zákazu - nedotýkat se vystavených exponátů. ${ }^{10}$ Vidí v něm př́ležitost $\mathrm{k}$ ozřejmění důvodů ochrany kulturního i přírodního dědictví, jejich akceptaci a následné uvědomělé dodržování, což je obecně jedno ze základních poslání muzejních institucí.

Pohledem současných trendů českého muzejnictví se jeví za ideální budování pomocné, studijní sbírky pro manipulaci v kontrolovaném a bezpečném prostředí. ${ }^{11}$ Pro muzejní kufříky a jiné aktivity konané mimo muzeum bez dohledu a kontroly muzejního pracovníka jsou nejvhodnější snadno dostupné repliky mincí. Muzejní pedagog tak může návštěvníkům ukázat sbírkový originál uložený bezpečně ve vitríně a zároveň jim do rukou svěřit věrnou repliku k podrobnějšímu studiu. At̉ už muzeum umožní svým návštěvníkům manipulaci s originálními mincemi, nebo replikami, je vhodné začlenit do takové manipulace pomůcky běžně užívané v numismatické praxi.

Rukavice, lupa, pinzeta, váha, digitální numismatická šuplera a další rozšiřují kontakt s hmotným předmětem o prožitek $\mathrm{z}$ badatelské práce. $\mathrm{K}$ bezpečnému a přehlednému uložení pomocné sbírky či sbírky replik poslouží

\footnotetext{
10 JAGOŠOVÁ, Lucie, Vladimír JŮVA a Lenka MRÁZOVÁ. Muzejní pedagogika: Metodologické a didaktické aspekty muzejní edukace. Brno: Paido, 2010, s. 219.

11 Například didaktická sbírka čítající na 25000 předmětů v rámci numismatické podsbírky Jihočeského muzea v Českých Budějovicích. Didaktický fond [online]. České Budějovice: Jihočeské muzeum v Českých Budějovicích, 2021 [cit. 2021-04-05]. Dostupný z www: <https://www.muzeumcb.cz/sbirky-1/historicka/ numismatika/didakticky-fond/>.
} 
například cenově dostupné numismatické kazety, které pak má muzejní pedagog ke své práci jednoduše připravené. Dále se často v návaznosti na numismatické exponáty objevují různá zařízení na vlastní ražbu mincí přímo v expozici či výstavě. ${ }^{12}$ Zážitek z vlastní ražby umocní celkový dojem z edukačního programu, ale může být rovněž využit v rámci jeho závěrečné reflektivní části shrnující v praktické ukázce teoretické poznatky o výrobě mincí v historii. Didaktických prostředků využitelných při zprostředkování numismatických témat existuje celá řada. Jejich začlenění do muzejní edukace vždy musí podléhat stanoveným výukovým cílům a metodám.

Pohledem tradičního dělení výukových metod dle J. Maňáka patří ve zprostředkování numismatického obsahu v muzejní edukaci mezi základní metody: předvádění a pozorování, manipulování, heuristické metody. ${ }^{13}$ Z dalších výukových metod definovaných Maňákem se jeví skupinová forma edukace jako vhodné řešení pro práci vícepočetné návštěvnické skupiny s drobnými exponáty (např. každá skupina se soustředí na jinou minci). Za podobným účelem lze využít též kooperativní práci ve skupině, která např́iklad může simulovat dělbu práce ve středověké mincovně, kde výroba mince byla vždy výsledkem součinnosti více jedinců.

U návštěvnické skupiny z řad široké veřejnosti, kde nevyhovuje kooperativní či skupinová forma, může nerovnováhu mezi počtem účastníků edukace a drobností exponátů kompenzovat samostatná práce $\mathrm{v}$ individuálních aktivitách. Tzv. učení v životních situacích

12 POLÁKOVÁ, Zdena a kol. Inspiration muzejní pedagogiky. Brno: Moravské zemské muzeum, 2010, s. 17.

13 MAŇÁK, Josef a Vlastimil ŠVEC. Výukové metody. Brno: Paido, 2003, s. 49.

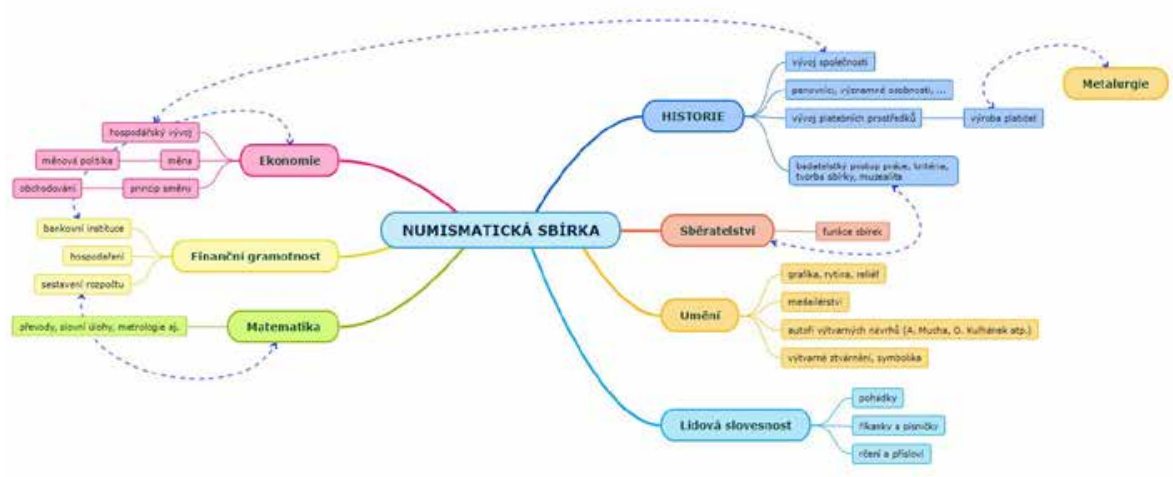

Obr. 1: Schematické znázornění tematické rozmanitosti numismatické sbírky.

se pak ve zprostředkování numismatických exponátů přirozeně nabízí s ohledem na každodenní kontakt návštěvníků s platidly. Tyto uvedené výukové metody představují spíše inspirativní a $\mathrm{v}$ autorčině praxi ověřený výběr. ${ }^{14}$ Konečná volba výukových metod podléhá u každého konkrétního edukačního programu řadě faktorů od stanovených cílů, přes osobnost muzejního pedagoga, cílovou skupinu až po zvolený obsah muzejní edukace.

\section{Numismatický obsah muzejní edukace}

Potenciál muzejního obsahu numismatických exponátů spočívá, jak už bylo výše v textu naznačeno, v pestrosti obsažených témat. Záleží tedy na každé konkrétní vzdělávací situaci, na muzejním pedagogovi, jaké téma bude akcentováno a jak bude zpracováno. Přesto se následující řádky pokusí naznačit možné tematické směry, z nichž si již každý muzejní pedagog může rozvinout jednotlivé téma sám dle daného edukačního programu a jeho cílů.

\footnotetext{
14 Stálé edukační programy k numismatické expozici Jihomoravského muzea ve Znojmě. Ukázka viz MAŽÁROVÁ, Monika. Návrh edukačních programů Domu umění Jihomoravského muzea ve Znojmě [online]. Brno: Masarykova univerzita, Filozofická fakulta, Ústav archeologie a muzeologie, 2012 [cit. 2021-04-09]. Bakalářská práce. Vedoucí Mgr. Lenka Mrázová. Dostupné z: $<$ https://is.muni.cz/th/hdsfc/ $>$.
}

Jako motivační téma v úvodu vstupní evokace edukačního programu lze aplikovat například výskyt názvů historických ražeb v lidové slovesnosti (viz Tab. 2), námětů a symbolů na platidlech z pohledu uměleckého či historického (podobizny panovníků, státní symboly, významné osobnosti dějin) a v případě novodobějších platidel připomenutí slavných autorů grafických předloh. Tyto aktivity edukačního programu přivedou účastníky přes známé pojmy $\mathrm{k}$ novým a přesnějším významům, a tak mohou skrze numismatiku přispět „k poznání historického obrazu vývoje naší společnosti nejen $v$ oblasti hospodářsko-obchodního a sociálního vývoje, ale i v oblasti kulturní historie, zejména však po stránce umělecko-historické. "15

Hlavní tematické jádro edukačního programu může spočívat například v oblasti historie, kde sleduje vývoj platebních prostředků, způsob výroby platidel, politickohospodářskou situaci dané společnosti. Soustředit se lze rovněž na metody a postupy numismatiky jako vědního oboru i sběratelské činnosti. Nikdy by neměl edukační program postrádat důraz na muzealitu, jedinečnou hodnotu

\footnotetext{
15 SEJBAL, Jiří (ed.). Vzdělávací a kulturně výchovná činnost v numismatice: sborník materiálů z numismatického semináře v Brně 1976. Brno: Moravské muzeum v Brně, 1979, s. 7.
} 


\begin{tabular}{|c|c|}
\hline Rčení a přísloví & Ř́kanky a písničky \\
\hline Groš v domě lepší než zlatý na cestách. & Já do lesa nepojedu \\
\hline Nezaslouží si dukátu, kdo neváží si groše. & Štěstí, zdraví, pokoj svatý \\
\hline Při hostech lépe je tolar škody, než za halíř ostudy. & Šnečku, šnečku, vystrč růžky \\
\hline Nestojí ani za zlámanou grešli. & \multirow{3}{*}{$\begin{array}{l}\text { Já jsem malý koledníček, } \\
\text { přišel jsem si pro trojníček, } \\
\text { trojníček mi dejte, } \\
\text { nic se mi nesmějte. }\end{array}$} \\
\hline Být jako za groš kudla. & \\
\hline Nespravedlivý groš vyžene iných koš. & \\
\hline $\begin{array}{l}\text { Jeden krejcar nespravedlivý vytahuje } \\
99 \text { spravedlivých. }\end{array}$ & $\begin{array}{l}\text { Když jsem šel přes Pražskej most, našel jsem } \\
\text { střibrnej groš: najed jsem se, napil jsem se, měl } \\
\text { jsem všeho dost. }\end{array}$ \\
\hline Za krále Holce byla za groš ovce. & \multirow{2}{*}{$\begin{array}{l}\text { Pěkná paní stojí, v bílé sukni chodí, ona do ní } \\
\text { sáhne, bílý groš vytáhne, nám ho daruje. }\end{array}$} \\
\hline Kouká jako poslední groš z pytlíku. & \\
\hline Nemám ani vindru. (vídeňský fenik) & \multirow{3}{*}{$\begin{array}{l}\text { Kovej, kovej, kováříčku! okovej mně mou } \\
\text { nožičku: až mi ji okováš, dám ti od ní groš. } \\
\text { Kovej, kovej, kovářičcku! okovej mně mou } \\
\text { nožičku, } 23 \text { okovej ji hezky, dám ti čtyry česky; } \\
\text { okovej mně obě, zaplatím já tobě. }\end{array}$} \\
\hline Nemám ani šesták. (šestikrejcar) & \\
\hline Nemám ani floka. (drobná husitská mince) & \\
\hline $\begin{array}{l}\text { Bylo to za babku. (drobná mince z Kutné Hory, } \\
\text { 15. st.) }\end{array}$ & \multirow{2}{*}{$\begin{array}{l}\text { Otloukej se, píštaličko! nebudeš-li se otloukali, } \\
\text { budu na té žalovali císaři pánu, on ti dá ránu, } \\
\text { že’s mi ukrad krávu: kráva stála za tolar, ty’s mi } \\
\text { za ni nic nedal. }\end{array}$} \\
\hline Stojí to za starou belu. (kůže z veverky) & \\
\hline Pro korunu by si nechal koleno vrtat. & \multirow{2}{*}{$\begin{array}{l}\text { O Velvary, o Velvary! kde jsou mé tolary? jed } \\
\text { jsem, pil jsem, hodoval jsem, hezké holky miloval } \\
\text { jsem: o Velvary, o Velvary! kde jsou mé tolary? }\end{array}$} \\
\hline Halíře dělají talíře. & \\
\hline & $\begin{array}{l}\text { Muziky, hrejte nám, však já vám krejcar dám; } \\
\text { však já vám zaplatím, jest-li ho neztratím - nebo } \\
\text { vám nic nedám. }\end{array}$ \\
\hline
\end{tabular}

Tab. 2: Př́iklady numismatických pojmů v lidové slovesnosti.

autentického svědectví, včetně jejího objasňování. ${ }^{16}$

Kromě humanitně zaměřených témat může muzejní pedagog ve svém programu odkazovat rovněž $\mathrm{k}$ matematice, kterou $\mathrm{k}$ sobě velmi těsně poutá právě numismatika ${ }^{17}$ a kterou může návštěvníkům zprostředkovat v praktickém užití (základní matematické operace, převody, slovní úlohy z běžného života atp.). Obdobně blízký vztah má numismatika $\mathrm{k}$ ekonomii. V rámci ní může

16 JAGOŠOVÁ, Lucie, Vladimír JŮVA a Lenka MRÁZOVÁ. Muzejní pedagogika: metodologické a didaktické aspekty muzejní edukace. Brno: Paido, 2010, s. 45.

17 PETRÁŇ, Zdeněk a Pavel RADOMĚRSKÝ. Encyklopedie české numismatiky. Praha: Libri, 1996, s. 13. návštěvníka provést obecně principy směny, obchodováním či hospodařením. Na průsečíku matematiky a ekonomie pak leží neméně významná finanční gramotnost. Jelikož právě finanční gramotnost v sobě ukrývá velký potenciál v muzejní edukaci, a to díky své celospolečenské potřebě $\mathrm{v}$ rámci formálního i celoživotního vzdělávání, bude se jí věnovat celý následující oddíl.

\section{Numismatika a společensky odpovědné muzeum}

Finanční gramotností se rozumí znalosti v problematice financí a dovednost správného hospodaření v běžném životě jednotlivce, příp. rodiny. Poprvé se začalo v České republice o finanční gramotnosti hovořit $\mathrm{v}$ roce $2005 .{ }^{18}$ Velkým tématem se ale stala až před rokem 2010 v souvislosti s doznívající ekonomickou krizí, která odkryla nekompetentnost jednotlivců naprííc společností v oblasti hospodaření a nedostatečnou orientaci ve využivání finančních služeb. Roku 2007 vznikl Standard finanční gramotnosti, který $\mathrm{v}$ revidované podobě definoval pro školní výuku základních a středních škol témata: „nakupování a placení, hospodaření domácnosti, přebytek rozpočtu domácnosti, schodek rozpočtu domácnosti. “19 Tento dokument pak sloužil rovněž jako východisko při začleňování finanční gramotnosti do školního vyučování.

Aktuálně platné kurikulární dokumenty však nezřizují nový vyučovací předmět, ale nechávají implementaci finanční gramotnosti na rozhodnutí jednotlivých škol. Jak uvádí oficiální dokument Ministerstva financí ČR: „... některé školy učí finanční vzdělávání jako samostatný předmět, někde se o téma finančního vzdělávání podělí více prededmětů, některé školy pro toto téma využívají projektové dny a existuji také školy, které $k$ výuce finanční gramotnosti přistupují pouze formálně, kdy např. svolají žáky do tělocvičny, kde jim udělá přednášku nějaký finanční poradce, který situaci může využít pro své podnikání." ${ }^{20}$

\section{Různorodost pojetí finanční} gramotnosti a absence samostatného vyučovacího předmětu představuje pro

\footnotetext{
18 Finanční vzdělávání a jeho vývoj v České republice [online]. Praha: Ministerstvo financí ČR, 2019, s. 11 [cit. 2020-12-10]. Dostupný z www: $<$ https://financnigramotnost.mfcr.cz/cs/proodborniky/strategicke-dokumenty $>$.

19 Standard finanční gramotnosti [online]. Praha: Ministerstvo financí ČR, 2017 [cit. 2020-12-10]. Dostupný z www: < https://financnigramotnost. mfcr.cz/cs/pro-odborniky/strategickedokumenty\#standard $>$.

20 Finanční vzdělávání a jeho vývoj v České republice [online]. Praha: Ministerstvo financí ČR, 2019, s. 13 [cit. 2020-12-10]. Dostupný z www: $<$ https://financnigramotnost.mfcr.cz/cs/proodborniky/strategicke-dokumenty $>$.
} 


\begin{tabular}{|l|l|l|l|}
\hline \multicolumn{2}{|c|}{ Základní vzdělávání 1. stupeň } & \multicolumn{2}{|c|}{ Základní vzdělávání 2. stupeň } \\
\hline Člověk a jeho svět & $\begin{array}{l}\text { Lidé kolem nás: } \\
\text { vlastnictví }\end{array}$ & Člověk a společnost & $\begin{array}{l}\text { Výchova k občanství: } \\
\text { naše vlast, člověk stát } \\
\text { a hospodářství (peníze) }\end{array}$ \\
\cline { 2 - 3 } & $\begin{array}{l}\text { Lidé a čas: orientace } \\
\text { v čase a časový řád }\end{array}$ & Člověk a svět práce & $\begin{array}{l}\text { práce s technickými } \\
\text { materiály, provoz } \\
\text { práce s drobným } \\
\text { materiálem: postup } \\
\text { badověba domácnosti } \\
\text { (finance), svět práce }\end{array}$ \\
\hline
\end{tabular}

Tab. 3: Příklad zastoupení finanční gramotnosti v RVP pro základní vzdělávání.

muzejní edukaci př́ležitost. Na poli finančního vzdělávání může dobře připraveným edukačním programem uplatnit všechny své prrirozené benefity pro formální vzdělávání - mezipředmětové vazby, propojení teoretické roviny s praktickou, prožitek kontaktu $\mathrm{s}$ autentickým sbírkovým předmětem atd. Muzejní pedagog se však musí správně zorientovat v ukotvení finanční gramotnosti $\mathrm{v}$ rámcových vzdělávacích programech, které je ve srovnání se samostatnými vyučovacími předměty svojí roztříštěností poněkud náročnější, jak ukazuje Tab. 3. Téma finanční gramotnosti je proto nutné hledat $s$ tematickou návazností učiva $\mathrm{v}$ různých vzdělávacích oblastech.

Generace, které se již dostává základům finanční gramotnosti ve školním vyučování, však stále ještě nedospěla do produktivního věku a převažující finanční nekompetentnost ve společnosti přestavuje trvalý problém..$^{21}$ Patrně se jedná o jeden $\mathrm{z}$ negativních reziduí komunistického režimu, jež společnost ideologicky udržoval $\mathrm{v}$ přesvědčení, že za blahobyt a finanční rozhodování nese

21 Dle měření finanční gramotnosti v roce 2015 se ukázalo, že na dvě třetiny respondentů se nechová ekonomicky zodpovědně. Viz Finanční vzdělávání a jeho vývoj v České republice [online]. Praha: Ministerstvo financí ČR, 2019, s. 17 [cit. 2020-12-10]. Dostupný z www: $<$ https://financnigramotnost.mfcr.cz/cs/proodborniky/strategicke-dokumenty $>$. zodpovědnost stát. ${ }^{22}$ Aktuálně platná Národní strategie finančního vzdělávání z roku 2019 proto rozšiřuje původní cílovou skupinu žáků základních a středních škol o kategorii dalšího vzdělávání dospělých, a to zejména osoby ohrožené sociálním vyloučením (lidé bez zaměstnání, na sociálních dávkách, senioři). Strategie rovněž zmiňuje nutnost zaměřit se také na pedagogy a pracovníky veřejné správy (např. sociální pracovníci), jejichž finanční vzdělání se pozitivně přenáší při výkonu povolání na cílové skupiny. ${ }^{23}$ A právě tyto cílové skupiny se jeví jako ideální potenciální návštěvníci edukačních programů zaměřených na finanční gramotnost $\mathrm{v}$ rámci numismatických expozic. Potřeba finančního vzdělávání navíc může $\mathrm{v}$ dohledné době opět více rezonovat společností $\mathrm{z}$ důvodu předvídané ekonomické krize jako důsledek pandemie COVID-19.

Nízká úroveň finanční gramotnosti se zpravidla projevuje nezvládnutím vyrovnaného hospodaření domácnosti a dlouhodobou dluhovou zátěží. Jak uvádí Ivan Bertl ve své publikaci, kromě dluhové pasti člověk často upadá pod psychickým tlakem do

22 BERTL, Ivan. Finanční gramotnost v kontextu rozvoje celoživotního učení dospělých: andragogické, metodické a psychologické souvislosti. Praha: Česká andragogická společnost, 2016, s. 52.

23 Národní strategie finančního vzdělávání 2.0 [online]. Praha: Ministerstvo financí ČR, 2020, s. 6 [cit. 2021-01-11]. Dostupný z www: <https:// financnigramotnost.mfcr.cz/cs/pro-odborniky/ strategicke-dokumenty $>$. přidružených problémů charakteru sociálně patologických jevů (napřr. různé druhy závislostí). Jedná-li se o rodinu, odráží se tento stav negativně také na péči o děti a jejich výchovu. V konečné fázi dochází $\mathrm{k}$ rozpadu rodiny. ${ }^{24}$ Jednotlivci si však zřejmě neuvědomují tyto dopady finanční negramotnosti, resp. zaujímají odosobněný postoj (tzv. "to se mně stát nemůže"), nebot', jak dokládá jeden z výzkumů, zájem o osobní rozvoj v oblasti finanční gramotnosti, zůstává mezi dospělými v rámci neformálního vzdělávání velmi nízký. ${ }^{25}$

A zde spočívá velká př́íležitost numismatických sbírek v muzeích. Návštěvník primárně přicházející do muzea za kulturním zážitkem a poznáním historie odchází díky edukačnímu programu rovněž motivován $\mathrm{k}$ poznání finančních základů. Muzeum v rámci celoživotního vzdělávání může nejen pomoci s šiřrením osvěty finanční gramotnosti, ale také s prevencí sociálně patologických jevů ve společnosti. Využitím numismatických sbírek či exponátů $\mathrm{s}$ výše uvedenými cíli plní muzeum své závazky vůči společnosti a staví se do role společensky odpovědné instituce.

Přirozeně tuto roli muzeum zastává v budování respektu ke kulturnímu dědictví a jeho ochraně, který je již z povahy muzejní instituce dalece nadřazený všem ostatním tématům obsažených ve zprostředkování numismatických sbírek. Významnost tohoto aspektu u předmětů numismatického charakteru úměrně narůstá se stále populárnějším hledáním pokladů detektorem kovů na zoraných polích. ${ }^{26}$ Muzejní edukaci v oblasti

\footnotetext{
24 BERTL, Ivan. Finanční gramotnost v kontextu rozvoje celoživotního učení dospělých: andragogické, metodické a psychologické souvislosti. Praha: Česká andragogická společnost, 2016, s. 54.

25 Tamtéž, s. 19.

26 Použití detektorů je $i v$ době koronaviru stále ilegální [online]. Praha: Národní památkový
} 
numismatických sbírek by tak neměla uniknout ani tato cílová skupinu více či méně poučených laiků, kteří se - za předpokladu dodržování daných pravidel mohou stát užitečným partnerem.

Muzejně edukační programy v různých formách tedy přinášejí potenciál oslovit kompletní návštěvnické spektrum - od školních skupin, přes obecnou veřejnost, návštěvníky ohrožené sociálním vyloučením až po poučené laiky. Daří-li se správně teoreticky a metodicky ukotvené edukační programy připravovat a realizovat, může muzeum nejen rozšiřovat svoji návštěvnickou základnu, ale také sbírku. Umožněním blízkého kontaktu s numismatickými předměty za dodržení základní bezpečnosti zvyšuje mezi návštěvníky zájem o numismatické exponáty i obor samotný, čímž udržuje sbírku stále „živou“.

Mince, spolu s dalšími numismatickými exponáty, představují velký zdroj mezioborového poznání. Jsou tematickým mostem humanitních věd $\mathrm{k}$ matematice a ekonomii a poskytují muzeu další možnost $\mathrm{k}$ naplnění své společenské úlohy. Téma finanční gramotnosti je zastoupeno v kurikulárních dokumentech českého školství i koncepcích celoživotního vzdělávání. Finanční gramotnost umožňuje představit numismatické exponáty v novém světle, oslovit další skupiny potenciálních návštěvníků a pozitivně naplňovat představu společensky odpovědného muzea. Nesnadnou interpretaci numismatických předmětů lze kompenzovat v rámci muzejních edukačních programů dostupnými didaktickými prostředky i vhodně zvolenými

ústav, 2020 [cit. 2021-01-20]. Dostupný z www: $<$ https://www.npu.cz/cs/npu-a-pamatkovapece/npu-jako-instituce/zpravy/60040-pouzitidetektoru-je-i-v-dobe-koronaviru-stale-ilegalni $>$. metodami, které článek uvedl spolu s tematickou rozmanitostí numismatických předmětů. S ohledem na jejich četné zastoupení a potenciál nastíněný v tomto didaktickém konceptu si však interpretace numismatických sbírek vyžaduje samostatnou metodickou podporu $\mathrm{v}$ teorii muzejní didaktiky, která dosud chybí.

\section{POUŽITÁ LITERATURA:}

BERTL, Ivan. Finanční gramotnost $v$ kontextu rozvoje celoživotního učení dospělých: andragogické, metodické a psychologické souvislosti. Praha: Česká andragogická společnost, 2016. ISBN 978-80-905460-3-5.

Didaktický fond [online]. České Budějovice: Jihočeské muzeum v Českých Budějovicích, 2021 [cit. 2021-04-05]. Dostupný z www: <https://www. muzeumcb.cz/sbirky-1/historicka/ numismatika/didakticky-fond/>.

DODD, Jocelyn. The socially purposeful museum. Museologica Brunensia, 2015, roč. 4, č. 2, s. 28-32. ISSN 1805-4722.

Finanční vzdělávání a jeho vývoj v České republice [online]. Praha: Ministerstvo financí ČR, 2019, s. 11 [cit. 202012-10]. Dostupný z www: <https:// financnigramotnost.mfcr.cz/cs/proodborniky/strategicke-dokumenty $>$.

HARRIS, Mieka. Are coins small and boring? Developing an experiential based education programme. Museum and Society [online], 2015, roč. 13, č. 2, s. 231-246 [cit. 2021-02-09]. Dostupný z www: <https://journals.le.ac.uk/ ojs1/index.php/mas/article/view/328>. ISSN 1479-8360.

https://doi.org/10.29311/mas.v13i2.328

HLAVÁČEK, Ivan, Rostislav NOVÝ a Jaroslav KAŠPAR. Vademecum pomocných věd historických. Jinočany: H \& H, 2002. ISBN 80-7319-004-4.

JAGOŠOVÁ, Lucie. Muzea a návštěvníci se speciálními vzdělávacími potřebami.

In Základy muzejní pedagogiky. Studijní texty. Brno: Moravské zemské muzeum, 2014, s. 41-57.

ISBN 978-80-7028-441-4.
JAGOŠOVÁ, Lucie, Vladimír JŮVA a Lenka MRÁZOVÁ. Muzejní pedagogika:

Metodologické a didaktické aspekty muzejní edukace. Brno: Paido, 2010. ISBN 978-80-7315-207-9.

KURZ, Karel. Metodika prezentace numismatického materiálu. In SEJBAL, Jiří (ed.). Vzdělávací a kulturně výchovná činnost $v$ numismatice: sborník materiálů z numismatického semináře v Brně 1976. Brno: Moravské muzeum v Brně, 1979, s. 17-24.

MAŇÁK, Josef a Vlastimil ŠVEC. Výukové metody. Brno: Paido, 2003.

ISBN 80-7315-039-5.

MAŽÁROVÁ, Monika. Návrh edukačních programů Domu umění Jihomoravského muzea ve Znojmě [online]. Brno:

Masarykova univerzita, Filozofická fakulta, Ústav archeologie a muzeologie, 2012 [cit. 2021-04-09]. Bakalářská práce. Vedoucí Mgr. Lenka Mrázová. Dostupné z: <https://is.muni.cz/th/hdsfc/>.

Národní strategie finančního vzdělávání 2.0 [online]. Praha: Ministerstvo financí ČR, 2020, [cit. 2021-01-11]. Dostupný z www: <https://financnigramotnost. $\mathrm{mfcr} . \mathrm{cz} / \mathrm{cs} /$ pro-odborniky/strategickedokumenty $>$.

ORNA-ORNSTEIN, John. Coins are small and boring: the importance of an education programme for a numismatic collection. In Actas de la VIII reunión del Comité Internacional de Museos Monetarios y Bancarios (ICOMON) = Proceedings of the 8th Meeting of the International Committee of Money and Banking Museums (ICOMON), Barcelona, 2001 [online]. Barcelona: Museu Nacional d'Art de Catalunya, 2003 [cit. 2021-01-22]. Dostupný z www: <http:// network.icom.museum/fileadmin/user_ upload/minisites/icomon/publications/eproceedings_pre_2006/Barcelona_2001/ John_Orna-Ornstein/Coins_are_small_ and_boring_-the_importance_of_an_ education_programme_for_a_numismatic collection.pdf $>$.

PETRÁŇ, Zdeněk a Pavel RADOMĚRSKÝ. Encyklopedie české numismatiky. Praha: Libri, 1996. ISBN 80-85983-09-5.

PINNOY, Věra. Principy společensky přínosného muzea na př́íkladu Galerie Středočeského kraje v Kutné Hoře. Museologica Brunensia [online], 2017, roč. 6, č. 2 [cit. 2020-12-10]. 
Dostupný z www: <https://

digilib.phil.muni.cz/bitstream/

handle/11222.digilib/137467/2_

MuseologicaBrunensia_6-2017-2_10.

pdf? sequence $=1>$.

ISSN 2464-5362. ISSN: 2464-5362.

POLÁKOVÁ, Zdena a kol. Inspiration muzejní pedagogiky 1. Brno: Moravské zemské muzeum, 2010. ISBN 978-80-7028-361-5.

Použití detektorů je i $v$ době koronaviru stále ilegální [online]. Praha: Národní památkový ústav, 2020 [cit. 2021-0120]. Dostupný z www: <https://www. npu.cz/cs/npu-a-pamatkova-pece/npujako-instituce/zpravy/60040-pouzitidetektoru-je-i-v-dobe-koronaviru-staleilegalni>.

SEJBAL, Jiří. Zhodnocení a perspektiva kulturně výchovné práce $\mathrm{v}$ numismatice v našich zemích. In SEJBAL, Jiří (ed.). Vzdělávací a kulturně výchovná činnost $v$ numismatice: sborník materiálů z numismatického semináře v Brně 1976. Brno: Moravské muzeum v Brně, 1979, s. $10-16$.
SEJBAL, Jiř́i (ed.). Vzdělávací a kulturně výchovná činnost $v$ numismatice: sborník materiálů z numismatického semináře v Brně 1976. Brno: Moravské muzeum v Brně, 1979.

Standard finanční gramotnosti [online]. Praha: Ministerstvo financí ČR, 2017 [cit. 2020-12-10]. Dostupný z www: <https://financnigramotnost. mfcr.cz/cs/pro-odborniky/strategickedokumenty\#standard $>$.

ŠOBÁŇOVÁ, Petra. Muzejní edukace. Olomouc: Univerzita Palackého v Olomouci, 2012. ISBN 978-80-244-3003-4.

ŠOBÁŇOVÁ, Petra a Michaela JOHNOVÁ ČAPKOVÁ. Plánování edukačních aktivit $v$ muzeu: od strategického plánu k př́pravě edukačního programu. Olomouc:

Univerzita Palackého v Olomouci, 2015. ISBN 978-80-244-4626-4.

VOREL, Petr. Od pražského groše ke koruně české: průvodce dějinami peněz $v$ českých zemích. Praha: Havran, 2004.

ISBN 80-86515-40-0.

\section{MONIKA MAŽÁROVÁ}

Jihomoravské muzeum ve Znojmě, Znojmo, Česká republika

mazarova@muzeumznojmo.cz

Dlouhodobě pracuje

v Jihomoravském muzeu ve Znojmě na pozici muzejního pedagoga a muzejní didaktiku také externě přednáší na Ústavu archeologie a muzeologie FF Masarykovy univerzity. Ve své teoretické práci i praxi se zaměřuje na regionální výuku v muzejním prostředí, strategické plánování a lektorské dovednosti. Spolupracovala na řadě výstav, publikací a projektů.

She has been working for a long time as a museum pedagogue in the South Moravian Museum in Znojmo. She also teaches museum didactics as an external lecturer at the Department of Archaeology and Museology, Faculty of Arts, Masaryk University. Her theoretical and practical work is focused on regional museum education, strategic planning, and lecturing skills. She collaborated on many exhibitions, publications and projects. 